\title{
PENGARUH KECERDASAN EMOSIONAL DAN LINGKUNGAN KERJA TERHADAP KINERJA KARYAWAN MELALUI KEPUASAN KERJA SEBAGAI VARIABEL INTERVENING
}

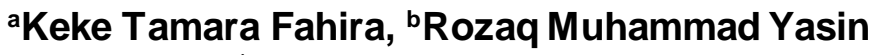 \\ $a, b$ Universitas Muria Kudus \\ keke.tamara@umk.ac.id
}

\author{
\begin{tabular}{l|l|l} 
Received : September & Accepted : October & Published: December
\end{tabular}
}

\begin{abstract}
The Business sector is facing intense competition around the world so that organizations recognize the importance of human resources as a competitive advantage. For this reason, the factors that have an influence on employee performance are discussed in this study including emotional intelligence, work environment and job satisfaction. This study aims to analyse the effect of emotional intelligence and work environment on employee performance through job satisfaction as intervening variable at PT. Indomaju Textindo Kudus. The quantitative method used in this research is using AMOS confirmatory analysis followed by Structural Equation Modeling (SEM). This research uses non probability sampling method (accidental sampling) in order to collect data. Primary data is used in the study by distributing 150 sample questionnaires to production employees at PT. Indomaju Textindo. The findings in this study are that emotional intelligence and work environment have a direct effect on employee performance. From the research results it can be concluded to improve the performance of employees at PT. Indomaju Textindo can be pursued by maintaining and improving the emotional intelligence of employees and a safe and comfortable work environment.
\end{abstract}

Keywords: Emotional Intelligence, Work Environment, Job Satisfaction, Employee Performance.

\section{ABSTRAK}

Sektor Bisnis menghadapi persaingan yang ketat di seluruh dunia sehingga organisasi menyadari pentingnya sumber daya manusia sebagai keunggulan kompetitif. Untuk itu faktor-faktor yang berpengaruh terhadap kinerja karyawan dibahas dalam penelitian ini antara lain kecerdasan emosional, lingkungan kerja dan kepuasan kerja. Penelitian ini bertujuan untuk menganalisis pengaruh kecerdasan emosional dan lingkungan kerja terhadap kinerja karyawan melalui kepuasan kerja sebagai variabel intervening pada PT. Indomaju Textindo Kudus. Metode kuantitatif yang digunakan dalam penelitian ini menggunakan analisis konfirmatori AMOS dilanjutkan dengan Structural Equation Modeling (SEM). Penelitian ini menggunakan metode non probability sampling (accidental sampling) untuk mengumpulkan data. Data primer digunakan dalam penelitian dengan menyebarkan 150 sampel kuesioner kepada karyawan bagian produksi di PT. Indomaju Textindo. Temuan dalam penelitian ini adalah bahwa kecerdasan emosional dan lingkungan kerja berpengaruh langsung terhadap kinerja karyawan. Dari hasil penelitian dapat disimpulkan untuk meningkatkan kinerja karyawan pada PT. Indomaju Textindo dapat diupayakan dengan menjaga dan meningkatkan kecerdasan emosional karyawan serta lingkungan kerja yang aman dan nyaman.

Kata Kunci: Kecerdasan Emosional, Lingkungan Kerja, Kepuasan Kerja, Kinerja Karyawan 


\section{PENDAHULUAN}

Sektor bisnis menghadapi persaingan yang ketat di seluruh dunia sehingga organisasi menyadari pentingnya sumber daya manusia sebagai keunggulan kompetitif organisasi. Tentunya sumber daya manusia tidak kalah berharga dari asset - asset perusahaan lainnya. Organisasi dituntut untuk dapat fokus pada faktor - faktor yang berkontribusi dengan baik dalam meningkatkan kinerja karyawan karena pada akhirnya kinerja karyawan akan menghasilkan kinerja organisasi secara keseluruhan (Markos \& Sridevi, 2010). Performance atau kinerja adalah output drive from processes, human or otherwise dimana kinerja merupakan hasil atau keluaran dari suatu proses (Sedarmayanti, 2001). Dengan demikian, organisasi telah menyadari pentingnya peningkatan kinerja karyawan karena tujuan organisasi tidak dapat dicapai kecuali jika kinerja karyawan memenuhi standar (Anitha, 2013). Dalam pengaturan organisasi, kinerja karyawan adalah hasil akumulasi dari keterampilan, upaya, dan kemampuan semua karyawan yang berkontribusi dalam peningkatan produktivitas organisasi yang mengarah pada pencapaian tujuannya (Dahkoul, 2018). Untuk itu, banyak perusahaan termasuk di PT. Indomaju Textindo melakukan berbagai upaya untuk meningkatkan kinerja karyawannya. Berikut data kinerja karyawan dari PT. Indomaju Textindo bagian produksi yang masih dikatakan kurang baik.

Tabel 1

Data Bagian Produksi Tahun 2019

\begin{tabular}{|c|c|c|c|c|}
\hline No & Bulan & Target & Tercapai & Efisiensi \\
\hline 1 & Januari & $1.168 .080 \mathrm{Kg}$ & $619.792,51 \mathrm{Kg}$ & $53,06 \%$ \\
\hline 2 & Februari & $1.058 .680 \mathrm{Kg}$ & $641.614,40 \mathrm{Kg}$ & $60,61 \%$ \\
\hline 3 & Maret & $1.233 .280 \mathrm{Kg}$ & $717.091,22 \mathrm{Kg}$ & $58,15 \%$ \\
\hline 4 & April & $1.227 .840 \mathrm{Kg}$ & $707.204,30 \mathrm{Kg}$ & $57,60 \%$ \\
\hline 5 & Mei & $1.231 .040 \mathrm{Kg}$ & $708.230,79 \mathrm{Kg}$ & $57,53 \%$ \\
\hline 6 & Juni & $973.040 \mathrm{Kg}$ & $576.030,90 \mathrm{Kg}$ & $59,20 \%$ \\
\hline 7 & Juli & $1.278 .080 \mathrm{Kg}$ & $798.812,70 \mathrm{Kg}$ & $62,50 \%$ \\
\hline 8 & Agustus & $1.207 .920 \mathrm{Kg}$ & $785.646,50 \mathrm{Kg}$ & $65,04 \%$ \\
\hline 9 & September & $1.238 .640 \mathrm{Kg}$ & $791.217,70 \mathrm{Kg}$ & $63,88 \%$ \\
\hline 10 & Oktober & $1.331 .760 \mathrm{Kg}$ & $886.882,80 \mathrm{Kg}$ & $66,59 \%$ \\
\hline 11 & November & $1.282 .400 \mathrm{Kg}$ & $761.976,40 \mathrm{Kg}$ & $59,42 \%$ \\
\hline 12 & Desember & $930.399 \mathrm{Kg}$ & $632.867,70 \mathrm{Kg}$ & $68,02 \%$ \\
\hline
\end{tabular}

Sumber: PT. Indomaju Textindo

Berdasarkan tabel 1 dapat dilihat data produksi bulan Januari dengan target $1.168 .080 \mathrm{Kg}$ hanya tercapai $619.792,51 \mathrm{Kg}$ dengan tingkat efisiensi $53,06 \%$, sehingga tidak dapat mencapai target yang telah ditentukan perusahaan. Untuk perhitungan efisiensi didapatkan dari $(619.792,51 \mathrm{Kg}: 1.168 .080 \mathrm{Kg}) \times 100 \%=53,06 \%$. Tingkat efisiensi pencapaian kinerja dari target yang seharusnya pada tahun 2019 rata - rata hanya tercapai di angka 50\% dan kurang dari 70\%. Pencapaian tertinggi ada pada bulan Desember namun hanya sebesar $68,02 \%$. Faktor yang mempengaruhi kurang maksimalnya kinerja karyawan harus diperhatikan dan PT. Indomaju Textindo perlu mengajarkan kepada para karyawan tentang masalah yang harus dihadapi dalam perusahaan dan karyawan harus agresif dalam hal performa bekerja agar mencapai sebuah target yang telah disepakati. Dalam target produksi bagian extruder yang telah ditentukan kebanyakan setiap bulannya tidak selalu tercapai.

Williams (2002) mengkonseptualisasikan job performance sebagai hasil kerja dan perilaku yang relevan dengan pekerjaan. Untuk itu menjadi penting bagi organisasi untuk mempertahankan karyawan yang memiliki kinerja baik. Kinerja karyawan yang baik tidak terlepas dari kondisi lingkungan kerja yang mendukung pula (Ellinger et al., 2003). 
Perusahaan telah melakukan langkah antisipasi salah satunya dengan memperhatikan lingkungan kerja yang mendukung bagi kinerja tiap karyawan. Lingkungan kerja sangat mempengaruhi sejauh mana karyawan terlibat dalam pekerjaan mereka dan berkomitmen pada organisasi. Saat ini keberhasilan dan kesuksesan dalam kerja tidak hanya didukung dari kemampuan intelektual saja, namun juga didukung oleh kemampuan mengelola emosi. Tidak heran jika menemukan orang yang tepat dalam organisasi bukanlah hal yang mudah, bukan hanya orang berpendidikan atau berbakat yang dibutuhkan, tetapi faktor psikologis yang mendasari hubungan antara seseorang dengan organisasinya (Boyatzis et al., 2000).

Dimana faktor psikologis ini dapat berpengaruh terhadap kemampuan seseorang didalam suatu organisasi. Goleman (2000) menyebut kemampuan tersebut sebagai Emotional Intelligence atau kecerdasan emosional. Tidak semua aspek pribadi dari karyawan merupakan kompetensi, hanya aspek pribadi yang dapat mendorong dirinya untuk mencapai kinerja yang optimal yang merupakan kompetensi salah satunya kecerdasan emosional (Cooper, R. K. \& Sawaf, 2002). Kecerdasan emosional yang tinggi mampu mengenal dirinya sendiri maupun berfikir rasional dan berperilaku positif serta mampu menjalin pemahaman emosi orang lain (Robbins \& Judge, 2013). Goleman (2002) mengungkapkan bahwa kecerdasan intelektual (IQ) menyumbang sekitar $20 \%$ bagi faktor yang menentukan kesuksesan dalam hidup, sedangkan $80 \%$ lainnya dipengaruhi oleh kekuatan lain termasuk kecerdasan emosional. Dalam pernyataan tersebut menunjukkan bahwa di dalam lingkungan kerja, aspek perilaku manusia mengambil peran yang sangat penting. Oleh karena itu kinerja dan prestasi yang diperoleh dalam pekerjaan salah satunya dipengaruhi oleh kecerdasan emosional yang menempati posisi pertama dan kecerdasan intelektual menempati posisi kedua (Nikolaou \& Tsaousis, 2002). Kecerdasan emosional juga membuat seseorang dapat menunjukkan integritasnya. Orang dengan kecerdasan emosional yang baik mampu berfikir jernih walaupun dalam tekanan, bertindak sesuai etika, berpegang pada prinsip dan memiliki dorongan berprestasi.

Terdapat temuan dari penelitian terdahulu mengenai pentingnya kecerdasan emosional dan lingkungan karyawan terhadap kinerja karyawan yang dijelaskan pada tabel berikut.

\section{Tabel 2}

\section{Temuan Research Gap}

\begin{tabular}{|c|c|c|c|}
\hline Variable & Pengaruh & Penulis & $\begin{array}{l}\text { Hasil } \\
\end{array}$ \\
\hline \multirow{5}{*}{$\begin{array}{c}\text { Kecerdasan } \\
\text { Emosional } \\
\text { dan Kinerja } \\
\text { Karyawan }\end{array}$} & \multirow[t]{3}{*}{ Signifikan } & $\begin{array}{l}\text { Vratskikh et al., } \\
(2016)\end{array}$ & $\begin{array}{l}\text { Emotional Intelligent memiliki korelasi positif } \\
\text { dan signifikan terhadap kinerja karyawan }\end{array}$ \\
\hline & & $\begin{array}{l}\text { Mohamad } \quad \& \\
\text { Jais, (2016) }\end{array}$ & $\begin{array}{l}\text { Kecerdasan emosional memiliki dampak } \\
\text { besar dan pengaruh yang signifikan pada } \\
\text { kinerja guru. }\end{array}$ \\
\hline & & $\begin{array}{l}\text { Dhani } \& \\
\text { Sharma, (2017) }\end{array}$ & $\begin{array}{l}\text { Terdapat efek positif } \text { dan signifikan } \\
\text { kecerdasan emosional terhadap kinerja } \\
\text { karyawan }\end{array}$ \\
\hline & \multirow[t]{2}{*}{$\begin{array}{l}\text { Tidak } \\
\text { Signifikan }\end{array}$} & $\begin{array}{l}\text { M. Kulkarni et } \\
\text { al., (2009) }\end{array}$ & $\begin{array}{l}\text { Kecerdasan emosional tidak } \text { memiliki } \\
\text { korelasi positif terhadap kinerja karyawan. }\end{array}$ \\
\hline & & Kahtani, (2013) & $\begin{array}{l}\text { Kecerdasan emosional memiliki pengaruh } \\
\text { tidak langsung terhadap kinerja karyawan. }\end{array}$ \\
\hline \multirow{3}{*}{$\begin{array}{l}\text { Lingkungan } \\
\text { Kerja dan } \\
\text { Kinerja } \\
\text { Karyawan }\end{array}$} & \multirow[t]{3}{*}{ Signifikan } & $\begin{array}{l}\text { Imran et al., } \\
(2012)\end{array}$ & $\begin{array}{l}\text { Lingkungan kerja berpengaruh positif dan } \\
\text { signifikan terhadap kinerja karyawan. }\end{array}$ \\
\hline & & $\begin{array}{l}\text { Bindu } \\
\text { Ollukkaran, } \\
\text { (2012) }\end{array}$ & $\begin{array}{l}\text { Lingkungan kerja di organisasi dapat } \\
\text { mempengaruhi kinerja karyawan. }\end{array}$ \\
\hline & & $\begin{array}{l}\text { Al-Omari } \\
\text { Okasheh, } \\
\text { (2017) }\end{array}$ & $\begin{array}{l}\text { Kendala situasional lingkungan kerja } \\
\text { berpengaruh langsung terhadap kinerja }\end{array}$ \\
\hline
\end{tabular}




\begin{tabular}{|c|c|c|c|}
\hline Variable & Pengaruh & Penulis & $\begin{array}{ll}\text { Hasil } \\
\end{array}$ \\
\hline & $\begin{array}{l}\text { Tidak } \\
\text { Signifikan }\end{array}$ & $\begin{array}{l}\text { Aryee et al., } \\
(2013)\end{array}$ & $\begin{array}{l}\text { Lingkungan kerja tidak berpengaruh secara } \\
\text { langsung terhadap kinerja karyawan. }\end{array}$ \\
\hline & & $\begin{array}{l}\text { Nzewi et al., } \\
(2017)\end{array}$ & $\begin{array}{l}\text { Lingkungan kerja tidak memiliki korelasi } \\
\text { positif terhadap kinerja karyawan. }\end{array}$ \\
\hline
\end{tabular}

Sumber: berbagai jurnal penelitian, data diolah

Dari beberapa penelitian diatas, masih terdapat banyak perbedaan hasil atau temuan dari berbagai penelitian terdahulu yang telah dilakukan sehingga terjadi ketidakkonsistenan hasil dan terdapat research gap. Oleh karena itu dalam penelitian ini, diadopsi variabel kepuasan kerja untuk menutup kesenjangan atau gap yang terjadi diantara perbedaan hasil penelitian terdahulu. Kepuasan kerja pada dasarnya merupakan pernyataan emosional yang positif atau menyenangkan sebagai dampak apresiasi karyawan terhadap pekerjaan dan pengalaman kerja. Setiap individu akan mempunyai tingkat kepuasan yang berbeda - beda sesuai dengan sistem nilai yang berlaku pada diri sendiri, semakin banyak aspek pekerjaaan, maka akan semakin tinggi pula tingkat kepuasan yang dirasakan atau sebaliknya.

Kepuasan kerja tergantung pada keseimbangan antara input peran kerja dan output peran kerja. Penelitian akan dilakukan di PT. Indomaju Textindo sebagai perusahaan yang memproduksi berbagai macam karung diantaranya ada karung plastik dan juga karung inner. Namun berdasarkan data dari PT. Indomaju Textindo kinerja karyawan bagian extruder masih bisa dikatakan kurang baik. Hal ini dikarenakan beberapa faktor termasuk faktor lingkungan kerja yang sangat berpengaruh dalam memotivasi karyawan. Selain itu, karyawan kurang agresif dalam hal performa kerja sehingga dalam target produksi bagian extruder yang telah ditentukan kebanyakan setiap bulannya tidak selalu tercapai. Kurangnya keyakinan dan kemampuan dalam hal emotional intelligence karyawan dalam menghadapi kesulitan terhadap tugas yang ada dibagian extruder. Terlebih lagi pada bagian lingkungan kerja juga diperlukan tempat yang nyaman bagi karyawan sewaktu bekerja. Penambahan ruang atau gudang pada bagian produksi yang sekarang ini masih kurang luas, serta penambahan ventilasi agar sirkulasi udara dapat bekerja dengan baik.

Pada saat memproduksi barang dengan jumlah yang banyak dan belum ada permintaan untuk mengirim, barang yang di gudang akan penuh sehingga karyawan bagian produksi akan susah mencari tempat lain. Karyawan juga kurang nyaman ketika bekerja, karena sirkulasi udara di ruangan produksi yang tidak berjalan dengan baik. Karyawan bagian produksi harus mampu bekerja secara maksimal dengan kemampuan dan keadaan yang belum bisa mendukung penuh untuk tetap bisa bekerja dan dapat bersaing dengan perusahaan-perusahaan sejenisnya. Beberapa hasil penelitian terdahulu terkait tentang pengaruh kecerdasan emosional dan lingkungan kerja terhadap kinerja karyawan ini umumnya masih meninggalkan gap, dimana hasil - hasil dari penelitian tersebut memberikan temuan yang berbeda. Untuk itu, penelitian ini dilakukan guna mengisi kesenjangan atau gap yang terjadi antar studi.

\section{Kinerja Karyawan}

\section{KAJIAN LITERATUR}

Kinerja karyawan dianggap sebagai apa yang dilakukan dan tidak dilakukan oleh karyawan. Kinerja merupakan tahapan pencapaian dalam menyelesaikan suatu pekerjaan tertentu (Simanjuntak, 2011). Kemudian menurut Santos et al., (2018) mendefinisikan kinerja kerja adalah kemampuan seseorang untuk melakukan aktivitas yang berkontribusi pada pengembangan inti teknis organisasi. Sehingga kinerja sering dianggap sebagai hasil yang dicapai oleh seseorang sesuai dengan ukuran yang berlaku untuk pekerjaan yang bersangkutan. Berdasarkan penjelasan diatas dapat disimpulkan bahwa kinerja adalah hasil kerja yang dilakukan oleh seseorang dalam periode tertentu dalam melaksanakan tugas dan tanggungjawab yang diberikan untuk mencapai sebuah tujuan (Yoke \& Panatik, 2015). 


\section{Lingkungan Kerja}

Lingkungan kerja dalam suatu perusahaan sangat penting untuk di perhatikan manajemen (Raziq \& Maulabakhsh, 2015). Menurut Aryee et al., (2013) melalui lingkungan kerja yang baik karyawan akan betah bekerja di perusahaan atau organisasi tersebut, meskipun kelihatannya remeh, tapi ternyata besar pengaruhnya terhadap efektivitas dan efesiensi pelaksanaan tugas. Lingkungan kerja melibatkan semua aspek yang bertindak dan bereaksi pada tubuh dan pikiran dari karyawan. Jika lingkungan kerja menyenangkan, maka kelelahan, monoton dan kebosanan diminimalkan dan kinerja bisa maksimal (Al-Omari \& Okasheh, 2017). Menurut Imran et al., (2012) umumnya faktor lain seperti tingkat kebisingan, udara segar, penyegaran juga menjadi bagian dari lingkungan kerja. Karyawan dapat bekerja lebih baik jika mereka diberikan lingkungan yang baik. Hasil kerja terkait langsung dengan lingkungan kerja, semakin kondusif lingkungan, semakin baik hasilnya (Nzewi et al., 2017). Kepuasan kerja sebagai rangkaian terintegrasi dari kondisi psikologis, fisiologis dan lingkungan yang mendorong karyawan untuk mengakui bahwa mereka puas atau senang dengan pekerjaannya.

Penelitian oleh Bindu \& Ollukkaran, (2012) juga sependapat bahwa lingkungan kerja berpengaruh positif terhadap kinerja karyawan. Hal ini karena tempat kerja merupakan hal primer yang memberikan efek langsung bagi psikologis masing-masing karyawan yang nantinya kinerja masing-masing individu akan meningkat atau bahkan menurun. Kemudian penelitian oleh Al-Omari \& Okasheh, (2017) bahwa lingkungan kerja memiliki korelasi positif terhadap kinerja karyawan. Hasil penelitian Raziq \& Maulabakhsh (2015) menunjukkan bahwa ada hubungan positif antara lingkungan kerja terhadap kepuasan kerja. Kesan nyaman terhadap lingkungan kerja dapat mengurangi rasa jenuh dan bosan dalam bekerja. Tentunya kenyamanan akan berdampak pada peningkatan motivasi dan menghasilkan kepuasan kerja karyawan. Sejalan dengan penelitian yang dilakukan oleh Henry Syauta et al., (2012) menyatakan bahwa lingkungan kerja memiliki pengaruh langsung terhadap kepuasan kerja para karyawan.

Lingkungan kerja yang kondusif dapat menjadikan karyawan merasa aman dan dapat bekerja secara optimal. Ketika karyawan merasa senang dengan lingkungan kerjanya maka karyawan tersebut akan lebih betah di tempat kerja untuk melakukan segala aktivitas dan menyelesaikan berbagai pekerjaannya. Namun, terdapat penelitian yang menyatakan pengaruh tidak langsung antara variabel lingkungan kerja terhadap kinerja karyawan melalui kepuasan kerja. Menguatkan hasil penelitian yang dilakukan oleh Ghofar \& Azzuhri, (2012) terdapat pengaruh signifikan variabel lingkungan kerja terhadap kinerja karyawan secara tidak langsung melalui kepuasan kerja. Penelitian Nabawi, (2019) menunjukkan pengaruh lingkungan kerja terhadap kinerja karyawan akan lebih besar jika melalui kepuasan kerja dibandingkan jika tanpa melalui kepuasan kerja. Indikasi ini bahwa perusahaan perlu untuk memperhatikan kepuasan kerja karyawannya terlebih dahulu sebelum berusaha meningkatkan kinerja karyawannya.

H2 : Lingkungan Kerja berpengaruh positif terhadap Kinerja Karyawan

H4 : Lingkungan Kerja berpengaruh positif terhadap Kepuasan Kerja.

H7 : Lingkungan Kerja berpengaruh positif terhadap Kinerja Karyawan melalui Kepuasan Kerja

\section{Kecerdasan Emosional}

Kecerdasan emosi merupakan wacana yang baru setelah bertahun-tahun masyarakat sangat meyakini bahwa faktor penentu keberhasilan hidup seseorang adalah IQ. Robbins \& Judges, (2013) mendefinisikan kecerdasan emosional (emotional intelligence) adalah kemampuan seseorang untuk menilai emosi dalam diri dan orang lain, memahami makna emosi dan mengatur emosi seseorang secara teratur. Menurut pakar kecerdasan emosional yaitu Daniel Goleman mengungkapkan bahwa kecerdasan intelektual (IQ) 
menyumbang sekitar $20 \%$ yang menentukan kesuksesan dalam hidup, sedangkan $80 \%$ lainnya dipengaruhi oleh kekuatan lain termasuk kecerdasan emosional. Kecerdasan emosional adalah kemampuan lebih yang dimiliki seseorang dalam hal menyadari emosi yang sedang terjadi dalam diri, mengendalikan emosi yang ada, memotivasi diri dalam menghadapi emosi, memiliki empati terhadap orang lain dan kemampuan berhubungan dengan orang lain (Kahtani, 2013). Seseorang dengan Emotional Intelligence (EI) yang tinggi juga mampu untuk memahami perasaan orang lain dalam menangani hubungan.

Banyaknya penelitian saat ini terkait kecerdasan emosional memenuhi peran penting dalam mencapai kinerja karyawan yang unggul di tempat kerja. Sejalan dengan penelitian yang telah dilakukan oleh Vratskikh et al., (2016) yang menyatakan bahwa kecerdasan emosional memiliki hubungan positif terhadap kinerja karyawan. Ketika seseorang cerdas secara emosional, maka memiliki kemampuan untuk mengendalikan emosi, yang akan mempengaruhi cara berhubungan dengan orang lain, kualitas hubungan, dan kesuksesan di tempat kerja. Hal ini juga didukung dengan hasil penelitian yang dilakukan Mohamad \& Jais, (2016) yang menyebutkan bahwa kecerdasan emosional berpengaruh positif dan signifikan terhadap kinerja karyawan. Kemudian menurut Dhani \& Sharma (2017) juga menyatakan bahwa kecerdasan emosional berkorelasi positif yang signifikan terhadap kinerja karyawan. Hal ini dikarenakan dengan kecerdasan emosional tentu akan mempegaruhi seseorang dalam mengambil keputusan. Penelitian oleh Yoke \& Panatik (2015) juga menyebutkan bahwa kecerdasan emosional berpengaruh positif terhadap kinerja karyawan.

Khan et al., (2012) menyatakan bahwa kecerdasan emosional memiliki pengaruh positif dan signifikan terhadap kinerja karyawan. Hal ini karena kecerdasan emosional tinggi lebih cenderung memiliki tingkat kepuasan kerja yang lebih tinggi karena mereka lebih mahir menilai dan mengatur emosi mereka sendiri daripada karyawan dengan emotional intelligence yang rendah. Sehingga karyawan dengan El tinggi mungkin lebih baik dalam mengidentifikasi perasaan frustrasi dan stres, dan kemudian, mengatur emosi tersebut untuk mengurangi stres. Penelitian lain yang dilakukan Seyal \& Afzaal, (2013) menunjukkan bahwa seluruh dimensi kecerdasan emosional mempengaruhi kepuasan kerja karyawan. Rezvani et al., (2016) juga menyatakan hal serupa bahwa kecerdasan emosional berpengaruh positif terhadap kepuasan kerja.

Namun terdapat berbagai penelitian yang menyatakan bahwa kecerdasan emosional dapat mempengaruhi kinerja karyawan apabila di jembatani oleh variable lain. Seperti hasil penelitian yang dilakukan oleh Sibasopait, (2018) yang menyatakan bahwa kecerdasan emosional berpengaruh terhadap kinerja karyawan apabila di mediasi oleh kepuasan kerja karyawan. Sehingga, kecerdasan emosional selain berpengaruh langsung terhadap kinerja juga berpengaruh secara tidak langsung terhadap kinerja melalui kepuasan kerja. Hal ini ditunjukkan dengan hasil penelitian yang dilakukan oleh Supriyanto \& Troena, (2012) bahwa kecerdasan emosional berpengaruh terhadap kinerja karyawan melalui kepuasan kerja. Seorang karyawan yang merasa bahagia dan memiliki kepuasan dalam bekerja akan melakukan kinerjanya dengan lebih baik. Penelitian yang dilakukan oleh Shooshtarian et al., (2013) mengungkapkan bahwa kepuasan kerja sebagai variable perantara antara hubungan kecerdasan emosional dan kinerja karyawan.

$\mathrm{H} 1$ : Kecerdasan Emosional berpengaruh positif terhadap Kinerja Karyawan.

H3 : Kecerdasan Emosional berpengaruh positif terhadap Kepuasan Kerja.

H6 : Kecerdasan Emosional berpengaruh positif terhadap Kinerja Karyawan melalui Kepuasan Kerja.

\section{Kepuasan Kerja}

Seseorang dengan kepuasan kerja yang tinggi biasanya memiliki sikap positif terhadap pekerjaannya. Kepuasan kerja menunjukkan adanya kesesuaian antara harapan seseorang yang timbul dengan imbalan yang disediakan oleh pekerjaan. Mathis et al., 
(2006) mengemukakan kepuasan kerja merupakan pernyataan emosional yang positif yang merupakan hasil evaluasi dari pengalaman kerja. Umar (2011) menyatakan bahwa kepuasan kerja ada hubungannya dengan apakah pekerjaannya mampu memenuhi harapan, kebutuhan,dan keinginannya. Kepuasan kerja adalah keadaan emosional yang menyenangkan atau tidak meyenangkan dimana para karyawan memandang pekerjaan mereka. Setiap individu memiliki tingkat kepuasan berbeda. Semakin banyak aspek dalam pekerjaan yang sesuai dengan individu maka semakin tinggi tingkat kepuasan yang dirasakan. Dalam penelitian yang dilakukan Hira \& Waqas, (2012) menyebutkan bahwa terdapat hubungan yang positif dan signifikan antara kepuasan kerja dan kinerja karyawan. Hal ini juga sesuai dengan hasil penelitian yang dilakukan Fu \& Deshpande (2014) bahwa terdapat hubungan yang positif dan signifikan antara kepuasan kerja dan kinerja. Kemudian penelitian Fadlallh (2015) juga sejalan bahwa kepuasan kerja dan kinerja saling berkorelasi positif. Didukung oleh penelitian dari Khan et al., (2012) bahwa kepuasan kerja berpengaruh positif terhadap kinerja karyawan.

H5 : Kepuasan Kerja berpengaruh positif terhadap Kinerja Karyawan.

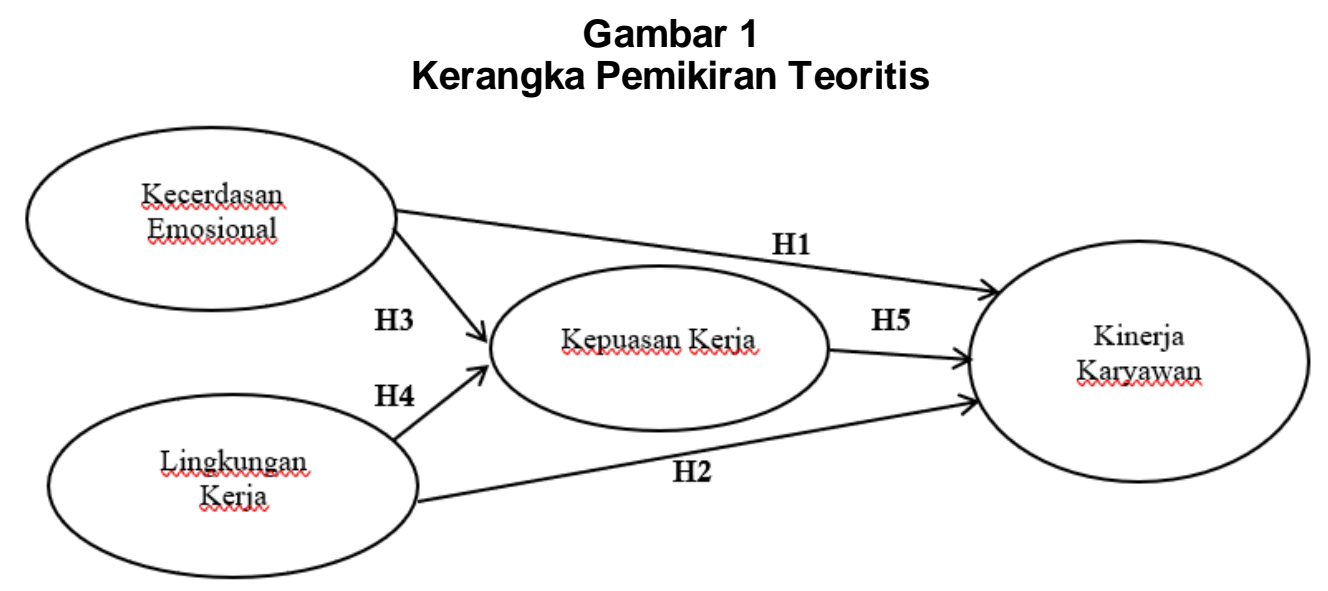

Sumber : Ollukkaran (2012); Waqas (2012); Maulabakhsh (2015); Rezvani et al (2016);

Vratskikh et al., (2016)

\section{Hipotesis :}

$\mathrm{H1}$ : Kecerdasan Emosional berpengaruh positif terhadap Kinerja Karyawan.

$\mathrm{H} 2$ : Lingkungan Kerja berpengaruh positif terhadap Kinerja Karyawan

H3 : Kecerdasan Emosional berpengaruh positif terhadap Kepuasan Kerja.

H4 : Lingkungan Kerja berpengaruh positif terhadap Kepuasan Kerja.

H5 : Kepuasan Kerja berpengaruh positif terhadap Kinerja Karyawan.

H6 : Kecerdasan Emosional berpengaruh positif terhadap Kinerja Karyawan melalui Kepuasan Kerja

H7 : Lingkungan Kerja berpengaruh positif terhadap Kinerja Karyawan melalui Kepuasan Kerja

\section{METODE}

\section{Jenis dan Sumber Data}

Penelitian ini menggunakan metode kuantitatif yang digunakan untuk menguji teori objektif dengan menganalisa hubungan antar variabel berkaitan dengan data dalam bentuk angka untuk menyelidiki fenomena atau gejala yang ada (Given, 2008). Pendekatan yang digunakan dalam penelitian ini adalah menggunakan analisis konfirmatori AMOS diteruskan dengan Structural Equation Modelling (SEM). Objek tempat penelitian ini PT. Indomaju Textindo Kudus yang berada di Jl. Getas Pejaten No.1 Kec. Jati, Kabupaten Kudus, Jawa Tengah. Data primer akan di peroleh dengan menyebarkan kuesioner tertutup kepada responden yang terpilih sebagai sampel dalam penelitian ini. Data sekunder didapat dari 
situs perusahaan langsung, arsip perusahaan, catatan serta dokumen perusahaan, dan sumber lainnya (Curtis, 2008).

\section{Populasi dan Sampel}

Populasi dalam penelitian ini adalah seluruh karyawan produksi yang berjumlah 735 karyawan di PT. Indomaju Textindo. Teknik pengambilan sampel menggunakan non probability sampling dengan metode accidental sampling. Dimana metode pengambilan sampel ini dilakukan terhadap responden dari anggota populasi yang secara kebetulan ditemui pada obyek penelitian ketika observasi sedang berlangsung (Notoatmodjo., 2010). Rules of thumb menurut Hair et al., (2014) menyatakan bahwa untuk model SEM (Structural Equation Modelling) ukuran sampel minimum yang terdiri dari lima atau lebih konstruk, masing-masing dengan lebih dari tiga item (variabel yang diamati), dapat secara memadai menggunakan 150 sampel. Penyebaran kuesioner dilakukan dari bulan November hingga Desember 2020.

\section{Definisi Operasional Variabel}

Definisi operasional variabel diberikan pada sebuah variabel dengan menspesialisasikan kegiatan yang diperlukan untuk mengukur variable tersebut (Nzir, 2017). Variabel independen dalam penelitian ini yaitu, variabel kecerdasan emosional (X1) dan lingkungan kerja (X2), variabel intervening yaitu kepuasan kerja, dan variabel dependen yaitu kinerja karyawan $(\mathrm{Y})$.

Tabel 3 Definisi Operasional Variabel

\begin{tabular}{|c|c|c|c|}
\hline Variabel & Definisi & Alat Ukur & Skala \\
\hline $\begin{array}{l}\text { Kecerdasan } \\
\text { Emosional }\end{array}$ & $\begin{array}{l}\text { kecerdasan emosional } \\
\text { adalah sebuah kemampuan } \\
\text { untuk mendengarkan bisikan } \\
\text { emosi dan menjadikannya } \\
\text { sebagai sumber informasi } \\
\text { maha penting untuk memiliki } \\
\text { kesadaran } \\
\text { diri yang memungkinkan } \\
\text { untuk mengenali perasaan- } \\
\text { perasaan dan mengelola } \\
\text { emosi sendiri (Issah., 2018). }\end{array}$ & 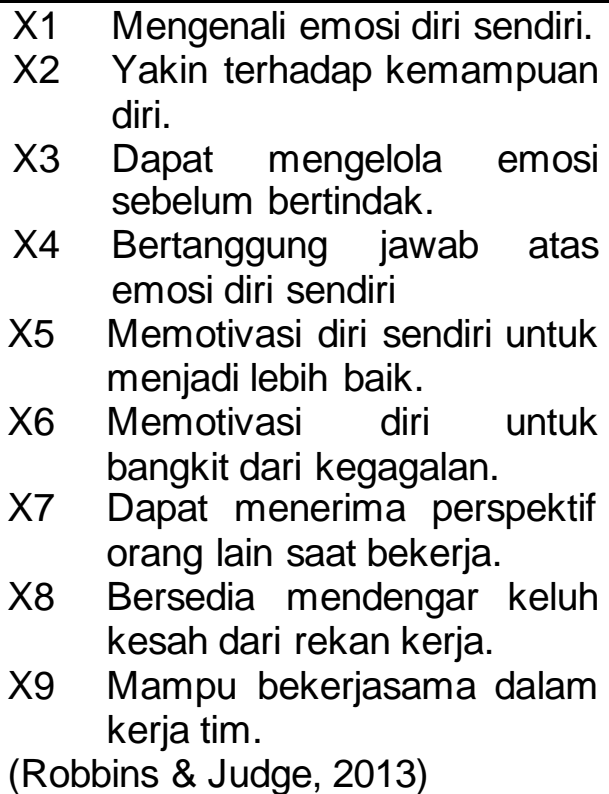 & $\begin{array}{l}\text { Likert } \\
1-7\end{array}$ \\
\hline $\begin{array}{l}\text { Lingkungan } \\
\text { Kerja }\end{array}$ & $\begin{array}{l}\text { Lingkungan kerja yang baik } \\
\text { menjadikan karyawan akan } \\
\text { betah bekerja di perusahaan } \\
\text { atau organisasi, meskipun } \\
\text { kelihatannya remeh, tapi } \\
\text { ternyata besar pengaruhnya } \\
\text { terhadap efektivitas dan } \\
\text { efesiensi pelaksanaan tugas } \\
\text { (Aryee et al., 2013). }\end{array}$ & $\begin{array}{ll}\text { X10 } & \begin{array}{l}\text { Ruang kerja tidak lembab } \\
\text { dan pengap. }\end{array} \\
\text { X11 } & \begin{array}{l}\text { Sirkulasi udara sejuk } \\
\text { membuat giat bekerja. }\end{array} \\
\text { X12 } & \begin{array}{l}\text { Lingkungan yang tidak } \\
\text { bising membuat fokus pada } \\
\text { pekerjaan. }\end{array} \\
\text { X13 } & \begin{array}{l}\text { Tingkat keamanan ditempat } \\
\text { kerja baik. }\end{array} \\
\text { X14 } & \begin{array}{l}\text { Kebersihan ditempat kerja } \\
\text { terjamin }\end{array} \\
\text { X15 } & \text { Penerangan yana cukup }\end{array}$ & $\begin{array}{l}\text { Likert } \\
1-7\end{array}$ \\
\hline
\end{tabular}




\begin{tabular}{|c|c|c|c|}
\hline & & $\begin{array}{c}\text { ditempat kerja. } \\
\text { (Sedarmayanti., 2001) }\end{array}$ & \\
\hline $\begin{array}{l}\text { Kepuasan } \\
\text { Kerja }\end{array}$ & $\begin{array}{lrr}\text { kepuasan kerja adalah } \\
\text { perasaan dan penilaian } \\
\text { seseorang atas } \\
\text { pekerjaannya, khususnya } \\
\text { mengenai kondisi kerjanya, } \\
\text { dalam hubungannya dengan } \\
\text { apakah pekerjaannya } \\
\text { mampu memenuhi harapan, } \\
\text { kebutuhan, dan } \\
\text { keinginannya (Umar., 2011). }\end{array}$ & $\begin{array}{ll}\text { Y1 } & \begin{array}{l}\text { Tantangan dalam pekerjaan } \\
\text { itu sendiri }\end{array} \\
\text { Y2 } & \begin{array}{l}\text { Atasan } \\
\text { semangat kerja mendorong }\end{array} \\
\text { Y3 } & \begin{array}{l}\text { Saling membantu jika terjadi } \\
\text { kesulitan dalam bekerja. }\end{array} \\
\text { Y4 } & \begin{array}{l}\text { Memiliki kesempatan untuk } \\
\text { promosi jabatan } \\
\text { Ypah diberikan secara }\end{array} \\
\text { Ypah layak. } & \\
\text { (Rezvani et al., 2016) }\end{array}$ & $\begin{array}{l}\text { Likert } \\
1-7\end{array}$ \\
\hline $\begin{array}{l}\text { Kinerja } \\
\text { Karyawan }\end{array}$ & $\begin{array}{l}\text { Kinerja karyawan adalah } \\
\text { kuantitas dan kualitas yang } \\
\text { dihasilkan atau jasa yang } \\
\text { diberikan oleh seseorang } \\
\text { yang melakukan pekerjaan } \\
\text { (Mathis et al., 2006). }\end{array}$ & \begin{tabular}{llr} 
Y6 & \multicolumn{2}{c}{$\begin{array}{l}\text { Menyelesaikan pekerjaan } \\
\text { sesuai standar kerja. }\end{array}$} \\
Y7 & $\begin{array}{l}\text { Menyelesaikan pekjaan } \\
\text { sesuai target }\end{array}$ \\
ditetapkan yang & $\begin{array}{l}\text { Menyelesaikan pekerjaan } \\
\text { tepat waktu }\end{array}$ \\
Y9 & $\begin{array}{l}\text { Menyelesaikan pekerjaan } \\
\text { secara efektif. }\end{array}$ \\
Y10 & $\begin{array}{l}\text { Bekerja secara konsisten } \\
\text { tanpa pengawasan atasan. }\end{array}$ \\
Y11 & $\begin{array}{l}\text { Dapat bekerjasama dalam } \\
\text { tim. }\end{array}$ \\
(Mathis et al., 2006)
\end{tabular} & $\begin{array}{l}\text { Likert } \\
1-7\end{array}$ \\
\hline
\end{tabular}

Sumber: Penelitian terdahulu, data diolah

\section{HASIL DAN PEMBAHASAN}

\section{Pengujian Konfirmatory Variabel Eksogen dan Endogen Sebelum Perbaikan Model}

Hasil pengolahan data dengan AMOS diperoleh standardized regression weights konfirmatory variabel eksogen endogen seperti pada tabel berikut.

Tabel 4

Standardized Regression Weights Variabel Eksogen dan Endogen Sebelum Perbaikan Model

\begin{tabular}{|c|c|c|c|c|c|c|}
\hline Variabel & Indikator & Estimate & Std C.R. & S.E. & C.R. & P \\
\hline $\begin{array}{c}\text { Kecerdasan } \\
\text { Emosional }\end{array}$ & $\mathrm{X} 01$ & 1,000 & 0,702 & & & \\
\cline { 2 - 7 } & $\mathrm{X} 02$ & 1,069 & 0,784 & 0,116 & 9,186 & ${ }^{* * *}$ \\
\cline { 2 - 7 } & $\mathrm{X} 03$ & 1,028 & 0,699 & 0,126 & 8,148 & ${ }^{* * *}$ \\
\cline { 2 - 7 } & $\mathrm{X} 04$ & 1,031 & 0,821 & 0,107 & 9,588 & ${ }^{* * *}$ \\
\cline { 2 - 7 } & $\mathrm{X} 05$ & 1,072 & 0,810 & 0,120 & 8,973 & ${ }^{* * *}$ \\
\cline { 2 - 7 } & $\mathrm{X} 06$ & 0,985 & 0,762 & 0,115 & 8,599 & ${ }^{* * *}$ \\
\cline { 2 - 7 } & $\mathrm{X} 07$ & 0,918 & 0,780 & 0,107 & 8,597 & ${ }^{* * *}$ \\
\cline { 2 - 7 } & $\mathrm{X} 08$ & 0,990 & 0,795 & 0,113 & 8,784 & ${ }^{* * *}$ \\
\cline { 2 - 7 } & $\mathrm{X} 09$ & 0,190 & $\mathbf{0 , 1 7 7}$ & 0,091 & 2,075 & 0,038 \\
\cline { 2 - 7 } & $\mathrm{X} 10$ & 0,305 & $\mathbf{0 , 2 5 6}$ & 0,102 & 2,987 & 0,003 \\
\hline
\end{tabular}




\begin{tabular}{|c|c|c|c|c|c|c|}
\hline & $\mathrm{X} 11$ & 1,000 & $\mathbf{0 , 5 9 8}$ & & & \\
\cline { 2 - 7 } & $\mathrm{X} 12$ & 1,246 & 0,711 & 0,181 & 6,876 & $* * *$ \\
\cline { 2 - 7 } & $\mathrm{X} 13$ & 1,486 & 0,800 & 0,207 & 7,187 & $* * *$ \\
\cline { 2 - 7 } & $\mathrm{X} 14$ & 1,577 & 0,791 & 0,218 & 7,227 & $* * *$ \\
\cline { 2 - 7 } & $\mathrm{X} 15$ & 1,434 & 0,806 & 0,198 & 7,248 & $* * *$ \\
\cline { 2 - 7 } & $\mathrm{X} 16$ & 0,468 & $\mathbf{0 , 2 0 2}$ & 0,206 & 2,269 & 0,023 \\
\hline Kepuasan Kerja & $\mathrm{Y} 01$ & 1,000 & 0,768 & & & \\
\cline { 2 - 7 } & $\mathrm{Y} 02$ & 1,158 & 0,896 & 0,098 & 11,859 & $* * *$ \\
\cline { 2 - 7 } & $\mathrm{Y} 03$ & 0,968 & 0,787 & 0,099 & 9,821 & $* * *$ \\
\cline { 2 - 7 } & $\mathrm{Y} 04$ & 0,860 & 0,730 & 0,096 & 8,952 & $* * *$ \\
\cline { 2 - 7 } & $\mathrm{Y} 05$ & 0,693 & $\mathbf{0 , 5 4 7}$ & 0,108 & 6,420 & $* * *$ \\
\hline Kinerja Karyawan & $\mathrm{Y} 06$ & 1,000 & $\mathbf{0 , 3 6 8}$ & & & \\
\cline { 2 - 7 } & $\mathrm{Y} 07$ & 2,221 & 0,940 & 0,478 & 4,642 & $* * *$ \\
\cline { 2 - 7 } & $\mathrm{Y} 08$ & 2,200 & 0,909 & 0,478 & 4,605 & $* * *$ \\
\cline { 2 - 7 } & $\mathrm{Y} 09$ & 1,250 & 0,717 & 0,287 & 4,357 & $* * *$ \\
\cline { 2 - 7 } & $\mathrm{Y} 10$ & 1,261 & 0,758 & 0,286 & 4,417 & $* * *$ \\
\cline { 2 - 7 } & $\mathrm{Y} 11$ & 1,422 & 0,769 & 0,320 & 4,438 & $* * *$ \\
\hline
\end{tabular}

Sumber: data diolah dengan AMOS 24

Hasil analisis CFA diatas terdapat 4 indikator dari 16 indikator yang digunakan dalam CFA variabel eksogen tidak dapat digunakan karena nilai loading faktor $<0,6$ yaitu pada indicator X09 (membangun hubungan baik dengan orang lain), X10 (mampu bekerjasama dalam kerja tim) dan X11 (ruang kerja tidak lembab dan pengap) serta X16 (Penerangan yang cukup ditempat kerja). Hasil analisis CFA untuk variable endogen terdapat 2 indikator dari 11 indikator yang tidak dapat digunakan karena nilai loading factor $<0,6$ yaitu pada indicator Y05 (upah diberikan secara layak) dan Y06 (menyelesaikan pekerjaan sesuai standar kerja).

\section{Pengujian Konfirmatory Variabel Eksogen Setelah Perbaikan Model}

Kesimpulan dalam CFA eksogen terdapat 4 indikator dari variabel laten kecerdasan emosional dan lingkungan kerja yang memiliki loading faktor di bawah 0,6. Terdapat 2 indikator dari variable kepuasan kerja dan kinerja karyawan yang memiliki nilai loading factor dibawah 0,6. Langkah selanjutnya adalah melakukan modifikasi model dengan membuang indikator yang memiliki loading faktor di bawah 0,6 sebagai berikut.

Tabel 5

Standardized Regression Weights Variabel Eksogen dan Endogen Setelah Perbaikan Model

\begin{tabular}{|c|c|c|c|c|c|c|}
\hline Variabel & Indikator & Estimate & Std C.R. & S.E. & C.R. & P \\
\hline \multirow{4}{*}{$\begin{array}{c}\text { Kecerdasan } \\
\text { Emosional }\end{array}$} & $\mathrm{X} 01$ & 1,000 & 0,702 & & & \\
\cline { 2 - 7 } & $\mathrm{X} 02$ & 1,069 & 0,784 & 0,116 & 9,186 & $* * *$ \\
\cline { 2 - 7 } & $\mathrm{X} 03$ & 1,028 & 0,699 & 0,126 & 8,148 & $* * *$ \\
\cline { 2 - 7 } & $\mathrm{X} 04$ & 1,031 & 0,821 & 0,107 & 9,588 & $* * *$ \\
\cline { 2 - 7 } & $\mathrm{X} 05$ & 1,072 & 0,810 & 0,120 & 8,973 & $* * *$ \\
\cline { 2 - 7 } & $\mathrm{X} 06$ & 0,985 & 0,762 & 0,115 & 8,599 & $* * *$ \\
\cline { 2 - 7 } & $\mathrm{X} 07$ & 0,918 & 0,780 & 0,107 & 8,597 & $* * *$ \\
\cline { 2 - 7 } & $\mathrm{X} 08$ & 0,990 & 0,795 & 0,113 & 8,784 & $* * *$ \\
\hline \multirow{4}{*}{ Lingkungan Kerja } & $\mathrm{X} 12$ & 1,246 & 0,711 & 0,181 & 6,876 & $* * *$ \\
\cline { 2 - 7 } & $\mathrm{X} 13$ & 1,486 & 0,800 & 0,207 & 7,187 & $* * *$ \\
\hline
\end{tabular}




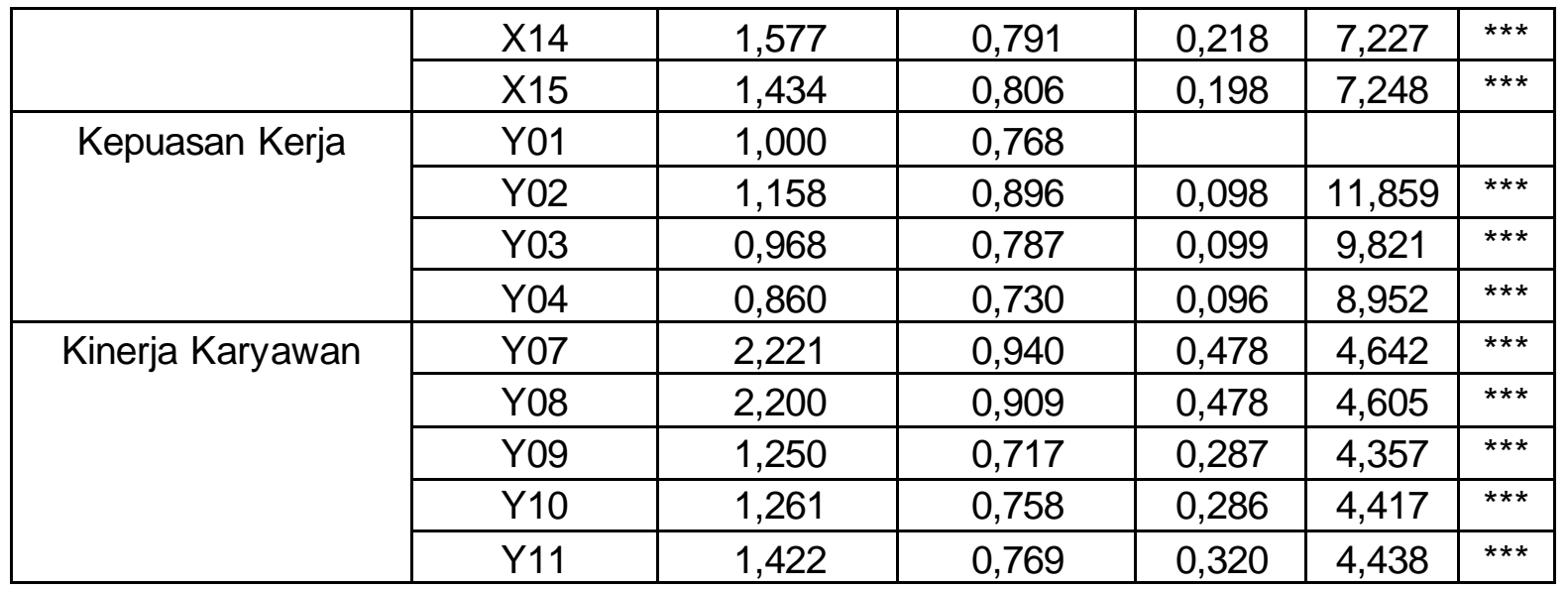

Sumber : data diolah dengan AMOS 24

\section{Uji Outlier}

Outlier multivariate dilihat dari mahalanobis d-squared tertinggi di bawah nilai kritis. Nilai kritis sebenarnya adalah nilai chi-square pada degree of freedom sebesar jumlah sampel pada taraf signifikanis 0,001. Sedangkan jumlah indikator dalam penelitian ini sebanyak 27 indikator pada tingkat $p<0,001$ dengan menggunakan rumus $X^{2}(27: 0,001)=$ 65,476. Hasil analisis menunjukkan jarak mahalanobis maksimal adalah 61,573. Hal ini menunjukkan tidak terdapatnya multivariate outliers sehingga eksekusi data tidak perlu dilakukan

\section{Pengujian Validitas Konstruk Full Model}

Hasil perhitungan variable Kecerdasan Emosional contruct reliability sebesar 0,921 dan variance extracted 0,593 . Variable Lingkungan Kerja contruct reliability sebesar 0,859 dan variance extracted 0,605 . Variable Kepuasan Kerja contruct reliability sebesar 0,874 dan variance extracted 0,636. Variable Kinerja Karyawan contruct reliability sebesar 0,949 dan variance extracted 0,704 . Dalam penelitian ini jumlah variabel yang diuji sebanyak 4 variabel. Hasil perhitungan nilai reliabilitas kontruk keempat variabel lebih besar dari 0.7. Kemudian untuk nilai variance exctracted untuk keempat variabel lebih besar dari 0.5 yang artinya indikator-indikator yang digunakan sebagai observed variabel relatif mampu menjelaskan variabel konstruk yang dibentuk.

\section{Pengujian Kelayakan Model}

Uji kesesuaian model konfirmatori diuji menggunakan goodness of fit yang meliputi chi square, probability, GFI, AGFI, TLI CFI, CMIN/DF dan RMSEA dalam penelitian ini dapat dilihat pada gambar 2 .

Dari gambar 2 di bawah ini, nilai goodness of fit dari full model SEM dapat dilihat pada tabel di bawah:

Tabel 6 Uji Full Model goodness of fit SEM

\begin{tabular}{|l|l|l|l|}
\hline \multicolumn{1}{|c|}{ Goodness of fit index } & \multicolumn{1}{|c|}{ Cut-of-value } & \multicolumn{1}{c|}{$\begin{array}{c}\text { Hasil } \\
\text { Analisis }\end{array}$} & \multicolumn{1}{c|}{ Keterangan } \\
\hline$x^{2}$-Chi Square & kecil $(\alpha=0,05 \mathrm{DF}=318)$ & 471,604 & Marginal \\
\hline Signifikansi Probablity & $\geq 0,05$ & 0,000 & Marginal \\
\hline GFI & $\geq 0,90$ & 0,796 & Marginal \\
\hline
\end{tabular}

\begin{tabular}{|l|l|l|l|}
\hline \multicolumn{1}{|c|}{ Goodness of fit index } & \multicolumn{1}{|c|}{ Cut-of-value } & $\begin{array}{c}\text { Hasil } \\
\text { Analisis }\end{array}$ & \multicolumn{1}{|c|}{ Keterangan } \\
\hline AGFI & $\geq 0,90$ & 0,757 & Marginal \\
\hline
\end{tabular}




\begin{tabular}{|l|l|l|l|}
\hline TLI & $\geq 0,90$ & 0,885 & Baik \\
\hline CFI & $\geq 0,90$ & 0,896 & Baik \\
\hline CMIN/DF & $\leq 2,0$ & 1,483 & Baik \\
\hline RMSEA & $\leq 0,08$ & 0,057 & Baik \\
\hline
\end{tabular}

Sumber : data diolah dengan AMOS 24

Dapat diketahui hasil chi square sebesar 471,604 dengan probabilitas $0,001 \leq 0,05$, nilai GFI 0,796 $\leq 0,90$, nilai AGFI 0,757 $\leq 0,90$, nilai TLI $0,885 \leq 0,90$, nilai CFI 0,896 $\leq 0,90$, nilai CMIN/DF $1,483 \leq 2,0$ dan nilai RMSEA sebesar $0,057 \leq 0,08$ dan yang menunjukkan bahwa uji kesesuaian model dinyatakan memiliki baik dan nilai marjinal mendekati model fit. Sehingga dalam penelitian ini dapat disimpulkan bahwa struktur analisis modelling dapat dilakukan.

\section{Gambar 2 \\ Hasil Uji Full Model Structural Equation Modelling (SEM)}

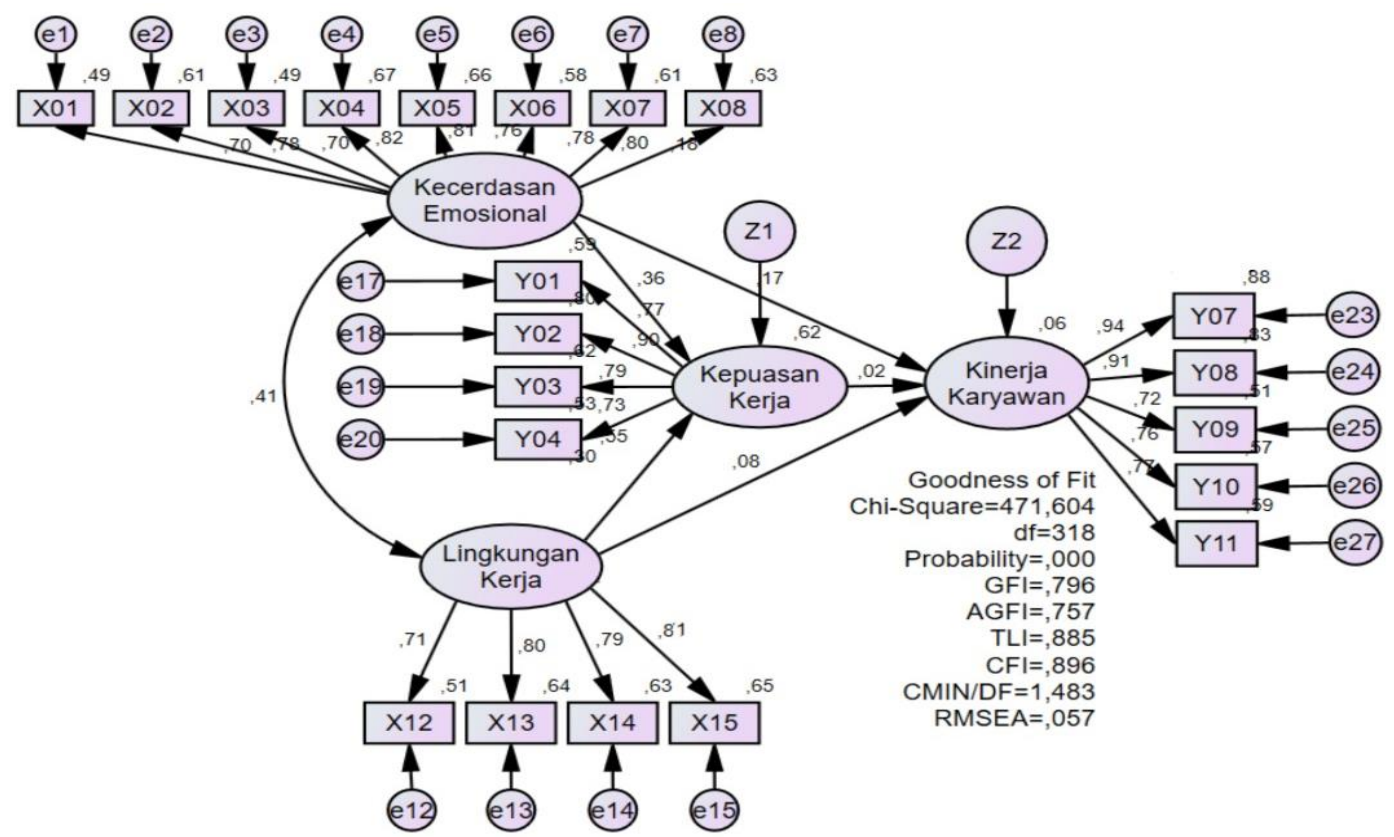

Sumber : data diolah dengan AMOS 24

\section{Analisis Squared Multiple Correlation}

Kemampuan menjelaskan variabel anteseden terhadap variabel konsekuen dalam model penelitian ini dapat dijelaskan melalui nilai $R$-square $\left(R^{2}\right)$ seperti berikut.

$\mathrm{Y} 1=0,124$ Kecerdasan Emosional $+0,521$ Lingkungan Kerja $+\varsigma 1 \mathrm{R}^{2}=0,301$

$Y 2=0,155$ Kecerdasan Emosional $+0,142$ Lingkungan Kerja $+\varsigma 2 R^{2}=0,386$

Nilai square multiple correlation dalam persamaan pertama adalah 0,301 yang mengindikasikan bahwa 30,1\% dari variabel nilai kepuasan kerja ditentukan oleh variabel kecerdasan emosional dan lingkungan kerja sedangkan sisanya yaitu sebesar 69,9\% dipengaruhi oleh variabel lain yang tidak diteliti dalam penelitian ini. Nilai square multiple correlation dalam persamaan kedua adalah 0,386 yang mengindikasikan bahwa $38,6 \%$ dari nilai kinerja karyawan ditentukan oleh variabel kecerdasan emosional dan lingkungan kerja sedangkan sisanya yaitu sebesar $61,4 \%$ dipengaruhi oleh variabel lain yang tidak diteliti dalam penelitian ini. 


\section{Hasil Penelitian (Uji Hipotesis)}

Berikut ini adalah output tabel pengujian hipotesis penelitian dengan menggunakan alat uji AMOS bentuk output Regression Weight seperti tabel berikut ini:

Tabel 7

Hasil Pengujian Regression Weights

\begin{tabular}{|lll|rrrrl|}
\hline & & & Estimate & S.E. & C.R. & P & Label \\
\hline KKer & $<---$ & KE & 0,360 & 0,082 & 4,370 & ${ }^{* * *}$ & par_11 \\
KKer & $<---$ & LK & 0,823 & 0,149 & 5,544 & $* * *$ & par_12 \\
KKar & $<---$ & LK & 0,071 & 0,129 & 2,555 & 0,032 & par_13 \\
KKar & $<---$ & KE & 0,109 & 0,074 & 2,475 & 0,014 & par_14 \\
KKar & $<---$ & KKer & 0,014 & 0,101 & 2,141 & 0,008 & par_15 \\
\hline
\end{tabular}

Sumber : data diolah dengan AMOS 24

Berdasarkan data dari hasil pengolahan data diketahui bahwa nilai CR 2,475 $\geq 1,96$ dan $\mathrm{P}$ (probability) $\quad 0,014<0,05$ sehingga dapat disimpulkan hipotesis 1 pada penelitian ini dapat diterima. Data dari hasil pengolahan data diketahui bahwa nilai CR 2,555 $\geq 1,96$ dan P (probability) 0,032<0,05 sehingga dapat disimpulkan hipotesis 2 pada penelitian ini dapat diterima. Data dari hasil pengolahan data diketahui bahwa nilai $\mathrm{CR} 4,370 \geq 1,96$ dan $\mathrm{P}$ (probability) $0,000<0,05$ sehingga dapat disimpulkan hipotesis 3 pada penelitian ini dapat diterima. Data dari hasil pengolahan data diketahui bahwa nilai CR 5,544 $\geq 1,96$ dan $P$ (probability) $0,000<0,05$ sehingga dapat disimpulkan hipotesis 4 pada penelitian ini dapat diterima. Data dari hasil pengolahan data diketahui bahwa nilai CR 2,141 $\geq 1,96$ dan $P$ (probability) 0,008 $<0,05$ sehingga dapat disimpulkan hipotesis 5 pada penelitian ini dapat diterima. Dengan kata lain, semua hipotesis yang diajukan dalam penelitian ini dapat diterima.

\section{Analisis Pengaruh Langsung, Tidak Langsung dan Total}

Analisis pengaruh langsung, tidak langsung dan total digunakan untuk mengetahui pengaruh variabel-variabel yang dihipotesiskan.

\section{Tabel 8}

\section{Pengaruh Langsung Variabel Laten}

\begin{tabular}{|l|crrr|}
\hline & KE & LK & KKer & KKar \\
\hline KKer & 0,124 & 0,521 & 0,000 & 0,000 \\
KKar & 0,155 & 0,142 & 0,486 & 0,000 \\
\hline
\end{tabular}

Sumber : Data primer yang diolah (2021)

Hasil pada tabel menunjukkan bahwa variabel kecerdasan emosional memiliki pengaruh langsung terbesar dengan arah positif terhadap variabel kinerja karyawan.

Tabel 9

Pengaruh Tidak Langsung Variabel Laten

\begin{tabular}{|l|ccrc|}
\hline & KE & LK & KKer & KKar \\
\hline KKer & 0,000 & 0,000 & 0,000 & 0,000 \\
KKar & 0,060 & 0,253 & 0,000 & 0,000 \\
\hline
\end{tabular}

Sumber : Data primer yang diolah (2021)

Hasil pada tabel menunjukkan bahwa variable kecerdasan emosional memiliki pengaruh tidak langsung terhadap kinerja karyawan, sehingga perlu variable kepuasan kerja 
untuk menjembatani antara kecerdasan emosional dengan kinerja karyawan. Variabel lingkungan kerja memiliki pengaruh tidak langsung terbesar dengan arah positif terhadap variabel kinerja karyawan.

\section{Pengaruh Total antar Variabel Laten}

\begin{tabular}{|l|ccrc|}
\hline & KE & LK & KKer & KKar \\
\hline KKer & 0,124 & 0,521 & 0,000 & 0,000 \\
KKar & 0,215 & 0,395 & 0,264 & 0,000 \\
\hline
\end{tabular}

Sumber : data diolah dengan AMOS 24

Berdasarkan tabel diatas bahwa variable lingkungan kerja memiliki pengaruh total terbesar terhadap variable kinerja karyawan.

\section{PEMBAHASAN}

Berdasarkan hasil olah data, kecerdasan emosional dan lingkungan kerja secara positif dan signifikan berpengaruh terhadap kinerja karyawan. Hasil penelitian pada $\mathrm{H} 1$ dan H2 memiliki hasil yang sama dengan penelitian terdahulu Vratskikh et al., (2016). Berdasarkan sebaran kuesioner, dapat dilihat faktor yang paling mempengaruhi kecerdasan emosional adalah bertanggung jawab atas emosi diri sendiri. Dimana seseorang yang bisa mengendalikan dan mengontrol emosi diri sendiri akan lebih mudah mencapai kinerja yang maksimal. Demikian pula faktor yang paling mempengaruhi lingkungan kerja berdasarkan sebaran kuesioner adalah penerangan yang cukup ditempat kerja. Melalui penerangan yang cukup, karyawan akan lebih optimal dalam bekerja, tidak merasa jenuh dan tidak mudah bosan sehingga kinerja yang maksimal akan lebih mudah tercapai. Penting untuk memperhatikan kondisi lingkungan tempat bekerja, jika lingkungan kerja menyenangkan, maka kelelahan, monoton dan kebosanan bisa diminimalkan dan kinerja menjadi lebih maksimal.

Selain itu, lokasi pekerjaan, tempat karyawan menjalankan tugas dan aktivitas sehari-hari, seperti kantor atau lokasi konstruksi, termasuk dalam lingkungan tempat kerja. Hal ini karena tempat kerja merupakan hal primer yang memberikan efek langsung bagi psikologis masing-masing karyawan yang nantinya kinerja masing-masing individu akan meningkat atau bahkan menurun. Berdasarkan literatur dan hasil penelitian terdahulu, ditemukan bahwa kecerdasan emosional dan lingkungan kerja berpengaruh positif dan signifikan terhadap kepuasan kerja. Sehingga pada H3 sejalan dengan penelitian Rezvani et al., (2016) dan Seyal \& Afzaal, (2013) yang juga menyatakan hal serupa bahwa kecerdasan emosional berpengaruh positif terhadap kepuasan kerja. Hal ini karena kecerdasan emosional tinggi lebih cenderung memiliki tingkat kepuasan kerja yang lebih tinggi karena mereka lebih mahir menilai dan mengatur emosi mereka sendiri daripada karyawan dengan emotional intelligence yang rendah. Sehingga karyawan dengan El tinggi mungkin lebih baik dalam mengidentifikasi perasaan frustrasi dan stres, dan kemudian, mengatur emosi tersebut untuk mengurangi stres.

Untuk hasil penelitian pada H4 juga sejalan dengan hasil penelitian Raziq \& Maulabakhsh (2015) dan Henry Syauta et al., (2012) yang menunjukkan bahwa ada hubungan positif antara lingkungan kerja terhadap kepuasan kerja. Kesan nyaman terhadap lingkungan kerja dapat mengurangi rasa jenuh dan bosan dalam bekerja. Tentunya kenyamanan akan berdampak pada peningkatan motivasi dan menghasilkan kepuasan kerja karyawan. Hasil penelitian untuk H5 sama dengan hasil penelitian terdahulu yang dilakukan Hira \& Waqas, (2012) serta Fu \& Deshpande (2014) yang menyebutkan bahwa terdapat hubungan yang positif dan signifikan antara kepuasan kerja dan kinerja karyawan. Hal ini dikarenakan semakin banyak aspek dalam pekerjaan yang sesuai dengan individu maka semakin tinggi tingkat kepuasan yang dirasakan. Ketika tingkat kepuasan sesuai dengan yang diharapkan karyawan maka akan mampu menciptakan kinerja karyawan yang 
maksimal. Kecerdasan emosional mendominasi pengaruh langsung terbesar terhadap kinerja karyawan, artinya kecerdasan emosional penting untuk selalu di tingkatkan. Selain itu lingkungan kerja juga memiliki pengaruh total terbesar terhadap kinerja karyawan yang artinya lingkungan kerja yang proporsional dan nyaman bagi karyawan akan meningkatkan kinerja karyawan di PT. Indomaju Textindo.

Sementara itu, hasil penelitian untuk H6 didukung oleh penelitian dari Sibasopait, (2018) bahwa kecerdasan emosional memiliki pengaruh tidak langsung terhadap kinerja karyawan sehingga variable kepuasan kerja dijadikan sebagai variable intervening. Hal ini dibuktikan dengan nilai pengaruh tidak langsung kecerdasan emosional terhadap kinerja karyawan sebesar 0,060. Meskipun variable kecerdasan emosional memiliki pengaruh langsung terbesar terhadap kinerja karyawan sebesar 0,155, tetapi pengaruh tidak langsung terhadap kinerja karyawan masih tetap ada dan cukup signifikan. Sehingga membuktikan bahwa kecerdasan emosional memiliki pengaruh tidak langsung terhadap kinerja karyawan melalui kepuasan kerja. Sejalan dengan penelitian yang telah dilakukan oleh Shooshtarian et al., (2013) yang mengungkapkan bahwa kecerdasan emosional memiliki pengaruh langsung terhadap kinerja karyawan apabila di jembatani oleh variable lain. Kecerdasan emosional justru akan mempengaruhi kepuasan kerja yang akan meningkatkan kinerja karyawan. Supriyanto \& Troena, (2012) juga menunjukkan bahwa kecerdasan emosional mempengaruhi kinerja melalui kepuasan kerja. Karyawan yang memiliki kecerdasan emosional yang tinggi akan merasa lebih puas dengan pekerjaan dan tentunya akan memiliki kinerja yang lebih baik daripada yang tidak puas dengan pekerjaan.

Lingkungan kerja selain berpengaruh langsung terhadap kinerja karyawan juga memiliki pengaruh tidak langsung terhadap kinerja karyawan melalui kepuasan kerja. Hasil penelitian ini didukung dengan penelitian yang dilakukan oleh Nabawi, (2019) yang menyatakan bahwa lingkungan kerja memiliki pengaruh tidak langsung terhadap kinerja karyawan sehingga harus melalui variable kepuasan kerja. Hal ini dibuktikan dengan nilai pengaruh tidak langsung variable lingkungan kerja terhadap kinerja karyawan sebesar 0,253 . Ini berarti bahwa lingkungan kerja memiliki pengaruh tidak langsung terbesar dengan arah positif terhadap kinerja karyawan.

Meskipun variable lingkungan kerja memiliki pengaruh langsung terhadap kinerja karyawan sebesar 0,142, namun pengaruh variable tidak langsung terhadap kinerja karyawan lebih besar. Sehingga hasil ini didukung oleh penelitian yang telah dilakukan oleh Ghofar \& Azzuhri, (2012) yang menyatakan bahwa terdapat pengaruh signifikan variable lingkungan kerja terhadap kinerja karyawan secara tidak langsung melalui kepuasan kerja. Sehingga dalam penelitian ini peran kepuasan kerja sebagai variabel antara (intervening) dapat dikatakan signifikan. Penelitian ini menunjukkan bahwa perusahaan perlu memperhatikan kepuasan kerja karyawannya terlebih dahulu sebelum berusaha meningkatkan kinerja karyawannya. Memperkuat pendapat Youssef \& Luthans, (2007) yang menyatakan apabila kondisi kerja bagus (misalnya, bersih, lingkungan menarik), karyawan akan lebih mudah menyelesaikan pekerjaan, sehingga apabila lingkungan kerja bagus maka tidak akan ada masalah dengan kepuasaan kerja karyawan.

\section{KESIMPULAN DAN SARAN}

\section{Kesimpulan}

Berdasarkan hasil utama dari penelitian yang telah dilakukan dan analisis terhadap data, dapat diketahui bahwa kecerdasan emosional dan lingkungan kerja berpengaruh positif signifikan terhadap kinerja karyawan. Artinya ketika kecerdasan emosional meningkat, maka kinerja karyawan pada PT. Indomaju Textindo juga akan mengalami peningkatan. Kecerdasan emosional dan lingkungan kerja berpengaruh positif dan signifikan terhadap kepuasan kerja. Artinya ketika kecerdasan emosional meningkat maka kepuasan kerja karyawan juga akan mengalami peningkatan. Kepuasan kerja berpengaruh positif signifikan terhadap kinerja karyawan yang artinya ketika kepuasan kerja terpenuhi maka kinerja karyawan juga akan meningkat. Dalam upaya meningkatkan kinerja pada karyawan 
di PT. Indomaju Textindo dapat diupayakan dengan mempertahankan dan meningkatkan kecerdasan emosional dari para karyawan dan lingkungan kerja yang aman dan nyaman. Penelitian ini juga menunjukkan bahwa perusahaan perlu memperhatikan kepuasan kerja karyawannya terlebih dahulu sebelum berusaha meningkatkan kinerja karyawannya.

\section{Saran}

Pihak perusahaan harus memberi perhatian lebih dengan bisa mempertahankan dan meningkatkan kecerdasan emosional. Hal itu dapat dilakukan dengan memberikan mentoring dan training kepada karyawan mengenai pentingnya kecerdasan emosional dalam dunia kerja. Pelatihan dan mentoring kecerdasan emosional bisa berupa pelatihan berkelompok secara periodik seperti character building. Hal tersebut bisa dilakukan melalui permainan, outbound, atau kegiatan sejenis yang akan melibatkan emosi karyawan, memahami karakter orang lain, dan memupuk semangat kerja sama antar sesama karyawan. Selain itu perusahaan perlu meningkatkan perhatian lebih terhadap lingkungan kerja fisik di PT. Indomaju Textindo seperti penanganan suhu udara yang disebabkan oleh alam misalnya kebutuhan karyawan akan udara yang bersih dan oksigen yang cukup agar tidak mengganggu pernafasan karyawan selama bekerja. Berdasarkan tanggapan responden, karyawan memilki kecerdasan emosional yang cukup baik. Namun, pelatihanpelatihan mengenai manajemen stress dapat menjadi salah satu solusi agar pegawai dapat mengatasi rasa stress yang timbul akibat pekerjaanya, selain itu melakukan acara gathering atau rekreasi seluruh pegawai secara berkala dapat meminimalisir rasa stress yang timbul.

Setelah melakukan penelitian di PT. Indomaju Textindo, masih terdapat beberapa hal yang menjadi hambatan dan keterbatasan pada penelitian ini. Beberapa keterbatasan tersebut adalah pada saat proses penyebaran kuesioner dan pengambilan data hanya bisa dilakukan pada watu - waktu tertentu saja karena dibatasi oleh regulasi perusahaan. Penelitian ini memverifikasi hipotesis melalui survei kuesioner yang hanya menyediakan data cross-sectional sehingga tidak dapat mengeksplorasi perubahan dinamis dari kecerdasan emosional, lingkungan kerja, kepuasan kerja dan kinerja karyawan dalam berbagai tahap. Berdasarkan keterbatasan pada penelitian ini, maka pada penelitian yang akan dilaksanakan selanjutnya sebaiknya memperluas karaktersitik dalam pemilihan sampling sehingga jika jumlah sampel yang diikutsertakan semakin besar, maka hasil penelitian dapat digeneralisir dengan baik. Penelitian mendatang dapat meneliti variabel kecerdasan emosional dan lingkungan kerja pada perusahaan jasa seperti Rumah Sakit (Shrestha, 2014) dan Jasa dibidang Keuangan (Raheja, 2018).

\section{REFERENSI}

Al-Omari, K., \& Okasheh, H. (2017). The influence of work environment on job performance: A case study of engineering company in Jordan. International Journal of Applied Engineering Research, 12(24), 15544-15550.

Anitha, J. (2013). Determinants of employee engagement and their impact on employee performance. https://doi.org/10.1108/lJPPM-01-2013-0008

Aryee, S., Chu, C. W. L., Kim, T. Y., \& Ryu, S. (2013). Family-Supportive Work Environment and Employee Work Behaviors: An Investigation of Mediating Mechanisms. Journal of Management, 39(3), 792-813. https://doi.org/10.1177/0149206311435103

Bindu, M., \& Ollukkaran, A. (2012). No Title.

Boyatzis, R. E., Goleman, D., \& Rhee, K. (2000). Clustering Competence In Emotional Intelligence: Insights From The Emotional Competencie Inventory The Handbook of Emotional Intelligence is available for purchase from Amazon . com. Handbook of Emotional Intelligence, 343-362. http://www.eiconsortium.org/pdf/eci_acticle.pdf

Cooper, R. K. \& Sawaf, A. (2002). Kecerdasan Emosional Dalam Kepemimpinan dan Organisasi. PT Gramedia.

Dahkoul, Z. M. (2018). The Determinants Of Employee Performance In Jordanian Organizations. 5, 11-17. https://doi.org/10.17261/Pressacademia.2018.780 
Dhani, P., \& Sharma, T. (2017). Effect of Emotional Intelligence on Job Performance of IT employees: A gender study. Procedia Computer Science, 122, 180-185. https://doi.org/10.1016/j.procs.2017.11.358

Dhiman, B., \& Raheja, S. (2018). Do Personality Traits and Emotional Intelligence of Investors Determine Their Risk Tolerance? Management and Labour Studies, 43(1-2), 88-99. https://doi.org/10.1177/0258042x17745184

Ellinger, A. D., Ellinger, A. E., \& Keller, S. B. (2003). Supervisory Coaching Behaviour, Employee Satisfaction and Warehouse Employee Performance: A Dyadic Perspective in the Distribution Industry. Human Resource Development Quarterly.

Fadlallh, A. (2015). Impact of Job Satisfaction on Employees Performance an Application on Faculty of Science and Humanity Studies University of Salman Bin Abdul-Aziz-Al Aflaj. International Journal of Innovation and Research in Educational Sciences, 2(1), 23495219.

Fu, W., \& Deshpande, S. P. (2014). The Impact of Caring Climate, Job Satisfaction, and Organizational Commitment on Job Performance of Employees in a China's Insurance Company. Journal of Business Ethics, 124(2), 339-349. https://doi.org/10.1007/s10551-013-1876-y

Ghofar, A., \& Azzuhri, M. (2012). Pengaruh Lingkungan Kerja Terhadap Kinerja Perawat Melalui Kepuasan Kerja Sebagai Variabel Intervening. 4.

Given, L. M. (2008). The SAGE Encyclopedia of Qualitative Research Methods. SAGE Publications, 1-4129-4163-6.

Goleman, D. (2000). Working with Emotional Intelligence. PT Gramedia Pustaka Utama.

Goleman, D. (2002). Emotional Intelligence. PT Gramedia Pustaka Utama.

Henry Syauta, J., Afnan Troena, E., \& Setiawan, M. (2012). The Influence of Organizational Culture, Organizational Commitment to Job Satisfaction and Employee Performance (Study at Municipal Waterworks of Jayapura, Papua Indonesia). International Journal of Business and Management Invention ISSN (Online, 1(1), 2319-8028.

Hira, A., \& Waqas, I. (2012). A Study of Job Satisfaction and IT' s Impact on the Performance in the Banking Industry of Pakistan. International Journal of Business and Social Sciences, 3(19), 174-180.

Imran, R., Fatima, A., Zaheer, A., Yousaf, I., \& Batool, I. (2012). How to boost employee performance: Investigating the influence of transformational leadership and work environment in a Pakistani perspective. Middle East Journal of Scientific Research, 11(10), 1455-1462. https://doi.org/10.5829/idosi.mejsr.2012.11.10.741

Issah, M. (2018). Change Leadership: The Role of Emotional Intelligence. https://doi.org/10.1177/2158244018800910

Kahtani, A. Al. (2013). Employee Emotional Intelligence and Employee Performance in the Higher Education Institutions in Saudi Arabia: A Proposed Theoretical Framework. International Journal of Business and Social Science, 4(9), 80-95. https://pdfs.semanticscholar.org/c085/8d46ed61d63a7075accd39175f4e8398da62.pdf? ga $=1.208263249 .213750356 .1490878367$

Khan, A. H., Nawaz, M. M., Aleem, M., \& Hamed, W. (2012). Impact of job satisfaction on employee performance: An empirical study of autonomous Medical Institutions of Pakistan. African Journal of Business Management, 6(7), 2697-2705. https://doi.org/10.5897/AJBM11.2222

M. Kulkarni, P., Janakiram, B., \& Kumar, D. N. S. (2009). Emotional Intelligence and Employee Performance as an Indicator for Promotion, a Study of Automobile Industry in the City of Belgaum, Karnataka, India. International Journal of Business and Management, 4(4). https://doi.org/10.5539/ijbm.v4n4p161

Markos, S., \& Sridevi, M. S. (2010). Employee Engagement: The Key to Improving Performance. 5(12), 89-96.

Mathis, John, \& Jackson, R. dan. (2006). Manajemen Sumber Daya Manusia. Salemba Empat.

Mohamad, M., \& Jais, J. (2016). Emotional Intelligence and Job Performance: A Study 
among Malaysian Teachers. Procedia Economics and Finance, 35(April), 674-682. https://doi.org/10.1016/s2212-5671(16)00083-6

Nabawi, R. (2019). Pengaruh Lingkungan Kerja , Kepuasan Kerja dan Beban Kerja Terhadap Kinerja Pegawai. 2(2), 170-183.

Nikolaou, I., \& Tsaousis, I. (2002). Emotional Intelligence In The Workplace:Exploring Its Effects On Occupational Stress And Organizational Commitment. The International Journal Of Organizational Analysis, 10, 327-342.

Nzewi, H. N., Augustine, A., Mohammed, I., \& Godson, O. (2017). Physical Work Environment and Employee Performance in Selected Brewing Firms in Anambra State. 2000, 1-19.

Nzir, M. (2017). Metode Penelitian (cetakan 11). PT. Ghalia Indonesia.

Raziq, A., \& Maulabakhsh, R. (2015). Impact of Working Environment on Job Satisfaction. Procedia Economics and Finance, 23(October 2014), 717-725. https://doi.org/10.1016/s2212-5671(15)00524-9

Rezvani, A., Chang, A., Wiewiora, A., Ashkanasy, N. M., Jordan, P. J., \& Zolin, R. (2016). Manager emotional intelligence and project success: The mediating role of job satisfaction and trust. International Journal of Project Management, 34(7), 1112-1122. https://doi.org/10.1016/j.ijproman.2016.05.012

Robbins, S. P., \& Judge, T. A. (2013). Organizational Behaviour (15th ed.). Pearson. http://library1.nida.ac.th/termpaper6/sd/2554/19755.pdf

Santos, A. S., Reis Neto, M. T., \& Verwaal, E. (2018). Does cultural capital matter for individual job performance? A large-scale survey of the impact of cultural, social and psychological capital on individual performance in Brazil. International Journal of Productivity and Performance Management, 67(8), 1352-1370. https://doi.org/10.1108/IJPPM-05-2017-0110

Sedarmayanti, M. (2001). Sumber Daya Manusia dan Produktivitas Kerja. Mandar Maju.

Seyal, A. H., \& Afzaal, T. (2013). An Investigation of Relationship among Emotional Intelligence, Organizational Commitment and Job Satisfaction: Evidence from Academics in Brunei Darussalam. International Business Research, 6(3), 217-228. https://doi.org/10.5539/ibr.v6n3p217

Shooshtarian, Z., Ameli, F., \& Aminilari, M. (2013). The Effect of Labor's Emotional Intelligence on Their Job Satisfaction, Job Performance and Commitment Keywords: Emotional Intelligence is one of the most important concepts introduced to psychology and management in the last decade. Thorndike In 1997, Mayer and Salovey described four abilities that contribute to emotional Intelligence: 1. Perception: It involves accurate verbal and non-verbal expression. 6(1), 29-45.

Shrestha, B. R. (2014). Emotional Intelligence at workplace in hospitals: Is it time to rejuvenate? Journal of Kathmandu Medical College, 2(2), 43-44. https://doi.org/10.3126/jkmc.v2i2.10621

Sibasopait, A. B. (2018). Pengaruh Kecerdasan Intelektual, Kecerdasan Emosional, Dan Kecerdasan Spiritual Terhadap Kinerja Melalui Kepuasan Kerja Tenaga Kependidikan Di Kantor Pusat Universitas Jember. Bisma, 12(2), 212. https://doi.org/10.19184/bisma.v12i2.7891

Simanjuntak, P. J. (2011). Manajemen \& Evaluasi Kerja (3rd edition). Fakultas Ekonomi Universitas Indonesia.

Supriyanto, A. S., \& Troena, E. A. (2012). Pengaruh Kecerdasan Emosional dan Kecerdasan Spritual Terhadap Kepemimpinan Transformasional, Kepuasan Kerja Dan Kinerja Manajer. Jurnal Aplikasi Manajemen, 10(66), 163-5241.

Umar, H. (2011). Riset Sumber Daya Manusia Dalam Organisasi. PT Gramedia Pustaka Utama.

Vratskikh, I., Masa'deh, R. (Moh'dTaisir), Al-Lozi, M., \& Maqableh, M. (2016). The Impact of Emotional Intelligence on Job Performance via the Mediating Role of Job Satisfaction. International Journal of Business and Management, 11(2), 69. https://doi.org/10.5539/ijbm.v11n2p69 
Williams, R. S. (2002). Managing employee performance: Design and implementation in organizations. Thompson Learning London.

Yoke, L. B., \& Panatik, S. A. (2015). Emotional intelligence and job performance among school teachers. Asian Social Science, 11(13), 227-234. https://doi.org/10.5539/ass.v11n13p227

Youssef, C. M., \& Luthans, F. (2007). Positive organizational behavior in the workplace: The impact of hope, optimism, and resilience. Journal of Management, 33(5), 774-800. https://doi.org/10.1177/0149206307305562 